\title{
TERRITORIAL ORGANIZATION FEATURES OF HEALTH CARE SYSTEM IN THE KYIV CITY METROPOLITAN AREA
}

\author{
Viktoriia OLIINYK \\ Taras Shevchenko National University of Kyiv, Ukraine \\ blanka3@mail.ru
}

\begin{abstract}
Article justifies the necessity of studying the development of medical services in Kyiv City metropolitan area. The essence of healthcare system is investigated and factors that influence it's development and deployment are identified. The component, management and territorial structure are analyzed and features of the territorial organization of healthcare system are revealed within the Kyiv City metropolitan area. The main indicators, which are the stimulants of this sector are mentioned: medical staff availability, amount of hospital beds and hospital facilities of different types. The author proposes the method of calculating the index of healthcare development, taking into account the stimulant's weights. This integral index has been applied for the analysis of healthcare system development within Kyiv City metropolitan area. The areas have been divided into the groups with the highest and lowest levels of healthcare system development. The main problems and prospects for development have been offered.
\end{abstract}

Key words: health care system, medical service, Kyiv City metropolitan area, territorial organization, index of development

UDC: 911.3

\section{ТЕРИТОРІАЛЬНІ ОСОБЛИВОСТІ РОЗВИТКУ СФЕРИ МЕДИЧНОГО ОБСЛУГОВУВАННЯ В МЕЖАХ КИЇВСЬКОї МІСЬКОї АГЛОМЕРАЦІї}

\author{
Вікторія олІйник \\ Київський начіональний університет імені Тараса Шевченка, Україна \\ blanka3@mail.ru
}

\begin{abstract}
Анотація: Обгрунтовано необхідність вивчення розвитку сфери медичного обслуговування Київської міськоїагломерації. Досліджено сутність сферимедичного обслуговуваннята з'ясовані основні чинники, що впливають наїірозвитокта розміщення. Проаналізовано компонентну, управлінську і територіальну структури та розкрито особливості територіальної організації сфери медичного обслуговування в межах Київської міської агломерації. Відображені основні показники, які $\epsilon$ стимуляторами
\end{abstract}

(c) В. Олійник 
розвитку даної сфери: забезпечення медичними кадрами, лікарняними ліжками та лікарняними закладами різного типу. Запропонована методика розрахунку індексу розвитку сфери медичного обслуговування, яка враховує вагові коефіцієнти виділених стимуляторів. На основі даного інтегрального показника проаналізовано територіальні відмінності рівня розвитку медичної сфери Київської міської агломерації, виділено території з найвищим та найнижчими рівнями розвитку. Сформовано основні проблеми та пропозиції щодо вдосконалення розвитку даної галузі.

Ключові слова: сфера медичного обслуговування, медична послуга, Київська міська агломерація, територіальна організація, індекс розвитку

\section{УДК: 911.3}

Вступ. Постановка проблеми. Актуальністю відзначається медико-географічний напрям досліджень здоров'я населення України та ㄲï регіонів, оскільки саме він дозволяє виявити вплив середовища проживання та зокрема територіальної організації суспільства на здоров'я населення. Наслідком постійного розвитку міста Києва та його приміської території є постійне збільшення кількості населення, що призводить до зростання попиту на послуги медичної сфери. Саме тому, важливо дослідити територіальні відмінності розвитку сфери медичного обслуговування, виявити їі проблеми та перспективи подальшого розвитку в межах Київської міської агломерації.

Аналіз останніх досліджень та публікацій. Регіональний розвиток системи охорони здоров'я як складової соціальної сфери відображений у наукових працях багатьох учених-економістів i практиків. Зокрема, значний внесок у розробку даної тематики здійснили Б. М. Андрушків, В. М. Геєць, Б. М. Данилишин, М. І. Долішній, С. І. Дорогунцов, А. Ф. Мельник, С. М. Писаренко, Д. М. Стеченко, I. Д. Фаріон, М. Г. Чумаченко та ін., у працях яких подано широкий спектр підходів до розв'язання проблем територіальної організації об'єктів соціального призначення.

Питання організації управління, фінансування системи охорони здоров'я та і1і реформування висвітлено у працях В. В. Баранова, Л. Г. Богуш, О. М. Голяченко, В. І. Євсеєва, В. М. Новікова, В. Ф. Попової, Л. Т. Шевчук, Ю. В. Шаленка та ін.

Формулювання цілей статті. Постановка завдання.Метоюстаттієдослідженнятериторіальних особливостей рівня розвитку медичної сфери Київської агломерації, а також визначення основних заходів оптимізації її територіальної структури.

Виклад основного матеріалу. Медичне обслуговування - це діяльність закладів охорони здоров'я та фізичних осіб-підприємців, які зареєстровані та одержали відповідну ліцензію в установленому законом порядку, у сфері охорони здоров'я [2].

Забезпечення належного стану здоров'я населення нашої держави є одним із найголовніших завдань України. Важливість сфери медичного обслуговування, в першу чергу, полягає у тому, що вона відіграє важливу роль у формуванні демографічного потенціалу території. Внаслідок дослідження системи охорони здоров'я та медичних послуг можна дійти висновку про те, що даний вид послуг містить не тільки соціальну складову, а й економічний ефект. Тому систему охорони здоров'я можна вважати важливою економічною складовою розвитку регіону чи країни.

В даний час сфера медичного обслуговування виконує покладені на неї функції перш за все за рахунок фінансування i належного державного регулювання. Загальний фонд зведеного бюджету на охорону здоров’я в Законі України «Про Державний бюджет України на 2013 рік» зі змінами визначено у сумі 53,8 млрд грн (3,4 \% від ВВП), у тому числі: місцеві бюджети - 41,2 млрд грн., державний бюджет - 11,7 млрд грн (з нього бюджет МО3 України - 6,9 млрд грн.). Видатки на охорону здоров'я у розрахунку на 1 жителя становлять 1180,6 грн [8].

Сучасний стан медичних послуг необхідно оцінювати, враховуючи ряд об'єктивних (діяльність закладів системи охорони здоров'я, матеріально технічне забезпечення, кадровий потенціал, рівень фінансування та інше), а також суб'єктивних (рівень захворюваності, частота відвідувань тих, чи інших закладів, тощо) факторів.

Київська міська агломерація - це моноцентрична агломерація із центром у м. Києві. До складу агломерації входить одне місто державного значення - Київ, чотири міста обласного значення - Ірпінь, Бориспіль, Бровари та Васильків та 6 районів[1]. Сфера медичного обслуговування на даній території представлена мережею закладів, що обслуговує населення в загальній кількості 2803 тис. осіб постійного, та 2845 тис. осіб наявного станом на 01.01.2013 p. [4]. Постійне збільшення кількості населення призводить до зростання навантаження на медичні установи. На даній території спостерігається недостатній рівень розвитку інфраструктури, матеріально - технічного та кадрового забезпечення медичного обслуговування. Тому виявлення проблем та обгрунтування перспектив розвитку даної галузі соціальної сфери є досить важливим.

Для дослідження сфери медичного обслуговування виділяють три основних їі структури: компонентна, територіальна та управлінська [6].

Компонентна структура формується на основі співвідношення на території медико-економічних та медико-соціальних параметрів функціонування галузей та видів господарської діяльності [6]. В наданні різних видів медичних послуг населенню участь беруть медичні заклади різного типу (табл. 1)

Найбільша кількість медичних закладів розташована в місті Києві. Це пояснюється тим, що Київ виконує функцію столиці та роль центру міської агломерації.

Основнимицентрамимедичногообслуговування, крім Києва, у яких склалась розгалужена компонентна структура даної агломерації $\epsilon$ місто Боярка, смт. Ворзель, смт. Глеваха. У цих населених пунктах 
медичні послуги населенню надаються переважно лікувально-профілактичними закладами, які мають обласне значення.

Запобіжний та поточний санітарний нагляд, організацію протиепідемічної роботи здійснює санітарно - епідеміологічна служба. Її основними закладами є санітарно - епідеміологічні станції різних рівнів і категорій, що функціонують у 6 - ти районах Київської міської агломерації та місті Києві.

На території агломерації розташовано 29 санаторіїв, зокрема, найбільша їх кількість у КиєвоСвятошинському районі. Відомими є курорти у смт. Ворзель («Зірка», «Кичеєво», «Ворзель», «Орлятко», «Перемога») та у місті Буча (оздоровчий табір «Відважний», ін..). Шість закладів даного типу зосереджено у Обухівському районі: у смт П'ятихатки - ДОЗ «Дозвілля» та ДОЗ «Каштан», у смт. Козин оздоровчий центр «Ярина» і оздоровчий комплекс «Пролісок». Також ще один санаторно-лікувальний комплекс розміщено у с. Пухівка, Броварського району.

У місті Києві розташовано 9 санаторнокурортних закладів. Більшість 3 них - це кліматичні курорти для медичного лікування та реабілітації загального профілю ( Пуща - Водиця, Маяк, Хвиля, Конча-Заспа, Пуща-Озерна, Жовтень, Пролісок), дитячий санаторій («Ластівка») та єдина в Україні бальнеологічна лікарня.

Функціонально-управлінська структура

це поєднання на певній території управлінських та контролюючих органів, що виконують певні охоронні, оздоровчі, регулятивні функції відповідно до існуючої ієрархічної субординації державних владних структур [6].

На основі проведеного аналізу було виявлено, що управлінська структура сфери медичного обслуговування Київської міської агломерації співпадає із управлінською структурою цієї сфери в межах всієї області. Вона охоплює три основні ієрархічні рівні: базовий, регіональний та державний.

Спеціалізована та вузькоспеціалізована допомога здійснюється закладами вищого рівня [7]. Така медична допомога надається у місті Києві, який виступає як державна ланка у системі ієрархії управління сферою охорони здоров'я. Це пов'язано iз розташуванням у столиці Міністерства охорони здоров'я України, що є головним виконавчим органом. На регіональному рівні він представлений основною управлінською структурою - Департаментом охорони здоров'я Київської обласної державної адміністрації та Департаментом охорони здоров'я виконавчого органу Київської міської ради (Київської міської державної адміністрації), який виконує роль регіонального органу управління в м. Києві [9].

Регіональне значення мають Центральні районні лікарні, як головні заклади охорони здоров'я в кожному районі: Бориспільська, Броварська, Васильківська, Вишгородська, Обухівська та КиєвоСвятошинська ЦРЛ. Регіональний рівень управління пов'язаний із діяльністю районних рад, в яких створені Департаменти охорони здоров'я.
Первинна медична допомога надається у територіально - структурних об'єктах найнижчого ієрархічного рівня, тобто на базових рівнях [7]. Такий вид послуг полягає: у наданні консультацій лікарем, простій діагностиці та лікуванні основних найпоширеніших захворювань, травм та отруєнь, направленні пацієнта для подання спеціалізованої i високоспеціалізованої допомоги. Основними структурними елементами первинної медикосанітарної допомоги у містах виступають поліклініки, консультації, диспансери, медчастини та пункти охорони здоров'я. У сільських місцевостях - це пункти охорони здоров'я, фельдшерські пункти.

Базовий рівень управління - це селищні ради. Їхні повноваження поширюються на медичні заклади, які знаходяться у комунальній власності. Приватні об'єкти володіють самоуправлінням. Базовий рівень управління є основним в системі медичної допомоги. Від якості та ефективності управління на цьому рівні залежать практично результати діяльності усієї системи управління сферою охорони здоров'я [6].

Територіальна структура сфери медичного обслуговування $\epsilon$ формою просторової організації медико-оздоровчого процесу в межах певної території. Вона представлена медичними пунктами, медичними центрами та медичними районами. Усі названі елементи утворюють місцеві, районні, міжрайонні, обласні та міжобласні системи медичного обслуговування [7].

Поєднання територіальної, компонентної та функціональної структур визначають територіальну організацію сфери медичного обслуговування.

Територіальна організація медичного обслуговування - це закономірний процес розміщення відповідних підприємств та установ, виникнення та функціонування їх просторових поєднань та системних утворень у тісній взаємодії 3 територіальними системами розселення i виробництва під впливом соціально - економічних та географічних чинників [6].

Територіальна організація сфери медичного обслуговування Київської міської агломерації формується під впливом багатьох чинників. Розташування закладів медичного обслуговування залежить від демографічних умов території, транспортного положення та розвитку транспортної інфраструктури, від кількості трудоресурсного потенціалу та наукових кадрів, які забезпечуватимуть нормальне функціонування закладів даного типу та чинної нормативно-правової бази.

Основу територіальної структури сфери медичного обслуговування Київської міської агломерації складає система розселення, що сформувалась різними типами населених пунктів, які виконують відповідні функції в процесі життєдіяльності суспільства [6].

У сфері медичного обслуговування спостерігається поетапність надання послуг. Основою є лікувально-профілактична допомога, яка має такі види - первинну (загальна лікарська допомога), вторинну (спеціалізована медична допомога) та третинну (вузькоспеціалізована медична допомога). 
Медичні послуги надаються за територіальним принципом 3 певною закономірністю: чим більша концентрація населення, тим ширший набір медичних послуг [5].

Особливістю територіальної організації на даній території є те, що у їі межах наявна столиця. Місто Київ має ряд спеціалізованих медичних закладів, які надають унікальні медичні послуги. За критичної необхідності населення може з усієї країни звертається до столичних лікарів переважно вузької спеціалізації. Це, наприклад, «Київський міський центр серця», «Центр мікрохірургії ока», Київська міська клінічна наркологічна лікарня «Соціотерапія», Міський медичний центр проблем слуху та мовлення «СУВАГ», Київський міський центр репродуктивної та перинатальної медицини та інші.

У місті Києві також розташовані заклади охорони здоров'я районного підпорядкування.

Особливим $є$ розташування обласних закладів охорони здоров'я. У зв'язку із соціальною та економічною завантаженістю столиці, доцільно винести лікарні обласного значення за іiі межі. Так, в межах агломерації розташовані - Обласна дитяча лікарня, Обласний будинок дитини, Обласна дитяча дерматологічна лікарня та Обласний протитуберкульозний диспансеру м. Боярка, Обласне спеціалізоване психіатрично-наркологічне медичне обєднання в смт. Глеваха, Обласна психоневрологічна лікарня № 2 у смт. Ворзель (входить в Ірпінську агломерацію). Але більшість закладів обласного значення (11) досі розташовуються в Києві, що ускладнює їх використання населенням області 3 точки зору транспортної доступності.

Інші заклади охорони здоров'я - центральні районні лікарні - розташовані у селищах міського типу та міські лікарні у містах даної агломерації, наприклад, Обухівська ЦРЛ, Вишгородська ЦРЛ та інші, які спеціалізуються на наданні загальної та спеціалізованої лікувально-профілактичної допомоги.

Спостерігається певна особливість надання медичних послуг у сільській місцевості в межах Київської міської агломерації. Надання медичних послуг на цих територіях включає послідовність у три етапи. Основним елементом організації територіальної структури при наданні медичних послуг сільському населенню на первинному рівні є сільська лікарська дільниця (СЛД), яка об'єднує дільничну лікарню, або самостійну лікарську амбулаторію, фельдшерсько-акушерські пункти. Наступним етапом $є$ районні медичні заклади. Ведучим закладом при цьому є центральна районна лікарня (ЦРЛ). На третьому етапі мешканці села отримують спеціалізовану та вузькоспеціалізовану медичну допомогу практично з усіх спеціальностей, в обласних закладах [5].

Для комплексного дослідження сфери медичного обслуговування Київської агломерації було проаналізовано кадрове забезпечення, наявність лікарняних закладів різного типу і забезпеченість лікарняними ліжками (табл. 2).

Методика дослідження включала розрахунок коефіцієнтів для кожного із вище наведених показників за формулою:

$$
\mathrm{K}=X / X \max ,
$$

де $\mathrm{K}$ - це значення коефіцієнта, X - значення показника для даної території, $\mathrm{X}_{\max }$ - максимальне значення показника території.

Дані показники є стимуляторами розвитку сфери медичного обслуговування. Тому чим більшим є значення показника, тим вищим буде значення коефіцієнта.

Для розвитку даної сфери необхідним є одночасне збільшення забезпеченості медичним персоналом, лікарняними ліжками та медичними закладами різного типу. Саме тому було обраховано загальний індекс розвитку галузі, що враховував всі коефіцієнти відповідно до їх вагового значення. На нашу думку, на перших два коефіцієнти вагове значення становить 20\% для кожного 3 них, оскільки вони відображають кадрове забезпечення сфери медичного обслуговування. На третій та четвертий коефіцієнт припадає по 30\%. Отже, індекс розвитку обраховується за формулою:

$$
\mathrm{I}_{\mathrm{PCMO}}=0,2 K_{1}+0,2 K_{2}+0,3 K_{3}+0,3 K_{4}
$$

де $\mathrm{I}_{\text {рсмо }}$ - індекс розвитку сфери медичного обслуговування, $\mathrm{K}_{1}, \mathrm{~K}_{2}, \mathrm{~K}_{3}, \mathrm{~K}_{4}$ - коефіцієнти показників розвитку.

Враховуючи значення підрахованих індексів була створена картосхема (Рис1), яка відображає територіальний розвиток сфери медичного обслуговування в межах Київської агломерації.

Найвищий індекс розвитку сфери медичного обслуговування спостерігається в м. Києві та Києво-Святошинському районі. Це пояснюється розташуванням значної кількості медичних закладів, що надають загальну та спеціалізовану медичну допомогу, високим рівнем матеріально технічного та кадрового забезпечення. Мінімальні значення індексу характерні для Васильківського та Броварського районів, оскільки дані території $€$ віддаленими від центру агломерації та рівень інфраструктурного забезпечення сфери медичного обслуговування є нижчим.

На основі проведеного аналізу стану розвитку сфери медичного обслуговування в межах Київської міської агломерації можна виділити наступні проблеми:

1. В Київській агломерації спостерігається збільшення кількості та питомої ваги осіб похилого віку. Окрім того необхідно враховувати, що серед народжених дітей лише біля 12 \% є цілком здоровими, інші ж народжуються 3 певними патологіями, i частина 3 них поповнить кількість інвалідів. Ці особливості демографічної ситуації посилюють навантаження на медичні установи.

2. Виникає ряд економічних проблем, які пов'язані із вартістю надання медичних послуг [9]. Це, в першу чергу, стосується закладів, що надають спеціалізовані медичні послуги та знаходяться у 
Таблиия 1

Кількість закладів медичного обслуговування Київської міської агломерації за типами в 2013 р.

\begin{tabular}{|c|c|c|c|c|}
\hline & $\begin{array}{c}\text { Кількість } \\
\text { лікарняних } \\
\text { закладів }\end{array}$ & $\begin{array}{c}\text { Кількість } \\
\text { амбулаторно- } \\
\text { поліклінічних } \\
\text { закладів }\end{array}$ & $\begin{array}{c}\text { Санаторно- } \\
\text { курортні } \\
\text { заклади }\end{array}$ & $\begin{array}{c}\text { Санітарно- } \\
\text { профілактичні } \\
\text { заклади }\end{array}$ \\
\hline м. Київ & 108 & 586 & 9 & 12 \\
\hline Бориспільський район & 23 & 37 & & 1 \\
\hline Броварський район & 16 & 24 & 1 & 1 \\
\hline Васильківський район & 12 & 40 & & 1 \\
\hline Вишгородський район & 26 & 42 & & 1 \\
\hline Києво-Святошинський район & 23 & 36 & 13 & 1 \\
\hline Обухівський район & 14 & 19 & 6 & 1 \\
\hline Загалом & 222 & 784 & 29 & 18 \\
\hline
\end{tabular}

Складено за матеріалами [3], [4]

Розвиток сфери медичного обслуговування Київської міської агломерації за 2013 р.

\begin{tabular}{|c|c|c|c|c|c|c|c|c|c|c|}
\hline & 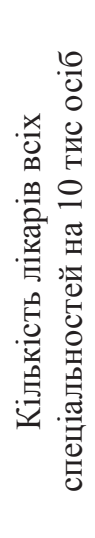 & K1 & 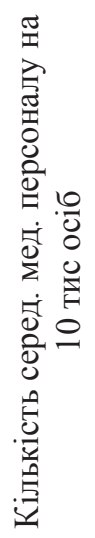 & $\mathrm{K} 2$ & 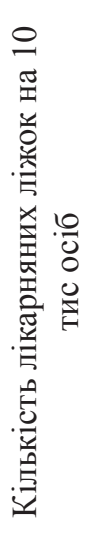 & K3 & 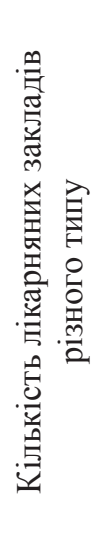 & K4 & 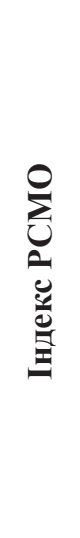 & 声 \\
\hline м. Київ & 82 & 1,00 & 111 & 0,88 & 104 & 0,95 & 715 & 1,00 & 0,96 & 1 \\
\hline Бориспільський район & 22,3 & 0,27 & 38 & 0,30 & 109 & 1,00 & 61 & 0,09 & 0,44 & 4 \\
\hline Броварський район & 29 & 0,35 & 53 & 0,42 & 54,2 & 0,50 & 42 & 0,06 & 0,32 & 6 \\
\hline Васильківський район & 24,5 & 0,30 & 41,6 & 0,33 & 59,6 & 0,55 & 53 & 0,07 & 0,31 & 7 \\
\hline Вишгородський район & 30,7 & 0,37 & 52 & 0,41 & 95,2 & 0,87 & 69 & 0,10 & 0,45 & 3 \\
\hline $\begin{array}{l}\text { Кисво-Святошинський } \\
\text { район }\end{array}$ & 67,3 & 0,82 & 126 & 1,00 & 55 & 0,50 & 73 & 0,10 & 0,54 & 2 \\
\hline Обухівський район & 15,2 & 0,19 & 38,6 & 0,31 & 106 & 0,97 & 40 & 0,06 & 0,41 & 5 \\
\hline
\end{tabular}

Складено за матеріалами [3], [4]

приватній власності.

3. Актуальною $є$ проблема транспортної доступності населення до надання медичних послуг. Особливо це стосується осіб, які проживають у сільській місцевості. Вони найчастіше звертаються або до місцевого медичного пункту, рідше - до районної лікарні. Користуючись одним і тим самим закладом охорони здоров'я вони не мають 


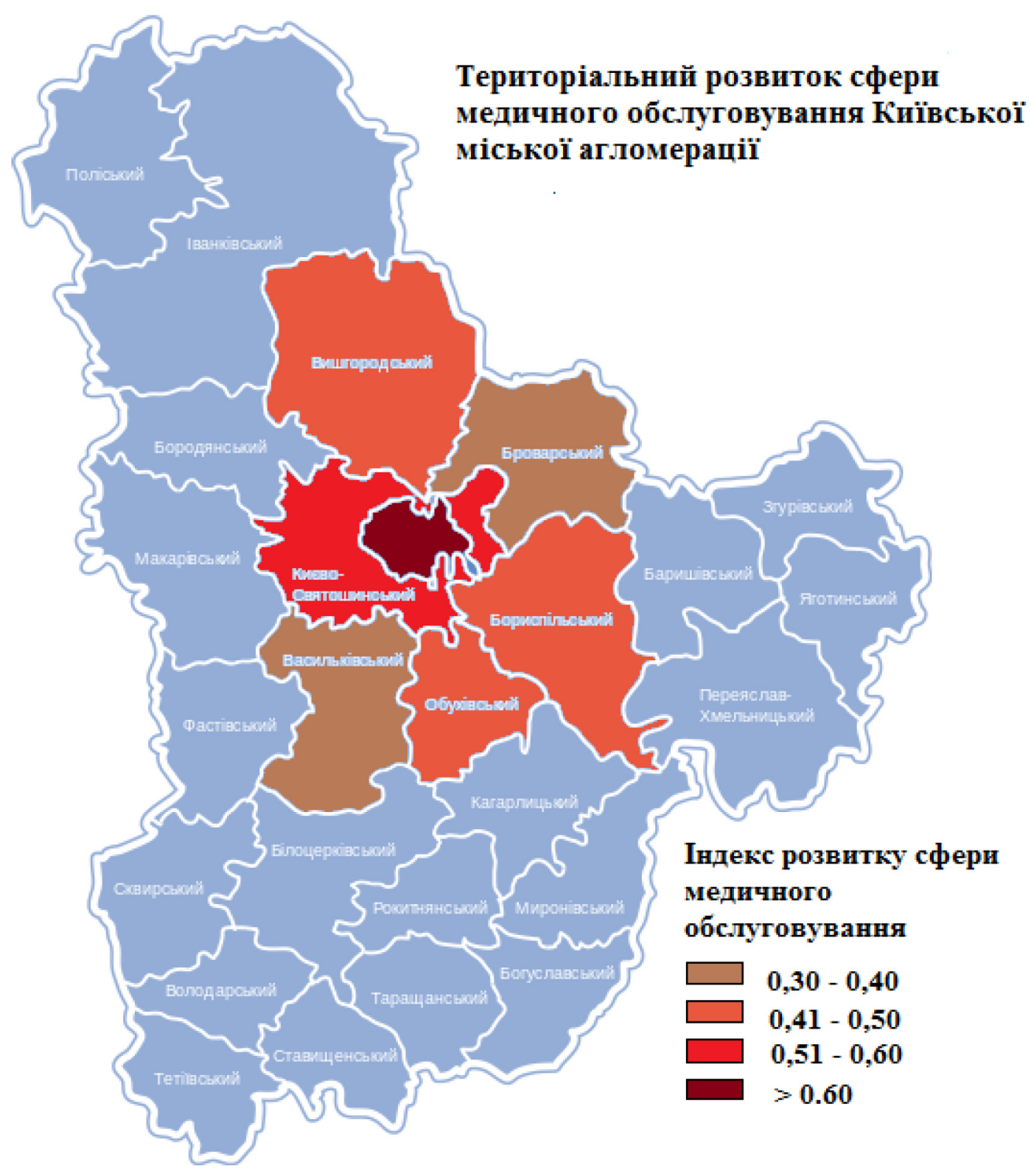

Рис. 1. Територіальний розвиток сфери медичного обслуговування Київської агломерації. Складено: Олійник В. В.

можливості порівняти якість надання послуг та рівень обслуговування.

4. Існують також екологічні проблеми, що впливають на функціонування медичної галузі. Наслідки інтенсивного використання екологічних систем негативно впливають на здоров'я, що, у свою чергу, призводить до зростання екологічно залежної патології, значних медичних та соціальноекономічних збитків для суспільства.

Висновки і перспективи подалыших розвідок. У зв'язку із наведеними вище проблемами, основні пріоритети у сфері організації охорони здоров'я доцільно сформулювати наступним чином:

1. Створити у складі центральних районних лікарень, міських лікарень консультативнодіагностичні центри.

2. Перенести лікарні обласного значення за межі міста Києва, оскільки він є досить завантаженим в результаті наявності великої кількості промислових та соціальних об'єктів. Потрібно створювати своєрідні спеціалізовані комплекси у ближніх містах, що розташовані навколо Києва. При цьому ці населені пункти у своїй діяльності в сфері охорони здоров’я будуть координуватись із столиці. Цей захід поліпшить доступність населення агломерації, а також всієї Київської області до медичного обслуговування обласного рівня.

3. Створити нові перинатальні центри, що допоможе у зниженні материнської та дитячої смертності.

4. Підпорядкувати лікарські амбулаторії центральним районним, центральним міським або міським лікарням Києва, як міста обласного значення. 
5. Одним з пріоритетних напрямків розвитку Київської агломерації $є$ поліпшення екологічної ситуації, оскільки вона впливає на стан здоров'я жителів. Для цього необхідним $є$ поширення зелених насаджень, винесення промислових підприємств за межі територій з високою концентрацією населення, встановлення очисних споруд та інше.

Отже, медична сфера розвивається в Київській агломерації досить динамічно, підвищується якість та різновидність наданих послуг. На формування рівня розвитку сфери медичного обслуговування впливає ряд факторів (демографічний, транспортний, ресурсний, нормативно-правовий та ін.). Варто відмітити, що в даній сфері обслуговування населення існує ряд проблем, які необхідно вирішити для подальшого вдосконалення медичного обслуговування. Розвиток даної сфери є досить важливим, оскільки забезпечення належного стану здоров’я населення нашої держави є одним із найголовніших завдань України.

\section{References:}

1. Alforov M. A. Urbanizacìnì procesi v Ukraïnì v 1945-1991 rr: Monografiâ [Urbanization processes in Ukraine in 1945-1991]. Donetsk, 2012, 420 p. (In Ukrainian).

2. Čaklin A. V. Geografiâ zdorov'â [Geography of Health]. Moscow, 1986, 28 p. (In Russian).

3. Golovne upravlinnâ statistiki m. Kiêva [Kyiv City Main Department of Statistics]. Available at: http://gorstat. kiev.ua/. (In Ukrainian).

4. Golovne upravlìnnâ statistiki u Kï̈vs'kij oblastì [Kyiv Oblast Main Department of Statistics]. Available at: http://oblstat.kiev.ukrstat.gov.ua/. (In Ukrainian).

5. Kucenko V. İ., Trìllenberg G. İ. Sfera ohoroni zdorov'â: socìal'no-ekonomičnì ta regional'nì aspekti [Socioeconomic and regional aspects of health protection]. Kyiv, 2005, 366 p. (In Ukrainian).

6. Martusenko İ. V. Metodika suspil'no-geografičnogo doslìdžennâ medičnogo kompleksu oblasnogo regìonu [Regional medical complex: methods of socio-geographical study]. Ekonomična ta social'na geografiâ [Economic and Social Geography], 2003, Vol. 54, pp. 139-145. (In Ukrainian).

7. Martusenko İ. V. Sučasnij stan, problemi ta perspektivi medičnoï geografiï Ukraïni [Current status, problems and prospects of medical geography in Ukraine]. Materìali vseukraïns'koï students'ko-aspirants'koï naukovoï konferenciï «Sučasnij stan, problemi ta perspektivi rozvitku doslìdžen'z geografičnih disciplìn ta kartografï v Ukraïnì» [Proceedings of National Conference "Current status, problems and prospects of research disciplines and geographic mapping in Ukraine"]. Ternopil, 2000, pp. 99-103. (In Ukrainian).

8. Rezul tati diâl'nostì galuzì ohoroni zdorov'â Ukraïni: 2013 rìk [The results of healthcare system operation in Ukraine: 2013]. Kyiv, 2014. Available at: http://www.uiph.kiev.ua/dawnload/Vidavnictvo/Rezultati\%20dijalnosti\%20 OZ.\%202013.pdf (In Ukrainian).

9. Stecenko S. G., Stecenko V. Û., Senûta İ. Â. Medične pravo Ukraïni: Pìdručnik [Ukrainian Medical Law: Textbook]. Kyiv, 2008, 86 p. (In Ukrainian).

10. Zakonoproekt «Pro zatverdžennâ Zagal'noderžavnö̈ programi «Zdorov'â-2020: ukrä̈ns 'kij vimir»». [The draft law on approval of the National Programme "Health 2020: Ukrainian Dimension"]. Available at: http://www.apteka. ua/article/132227. (In Ukrainian). 